\title{
Writing Matrix and Assessing Literature Review: A Methodological Element of a Scientific Project
}

\author{
Erni Murniarti \\ Educational Management, Universitas Kristen Indonesia \\ E-mail: ernims3@gmail.com \\ Bernard Nainggolan \\ Department of Law, Postgradute School, Universitas Kristen Indonesia \\ E-mail: nainggolanbernard1@gmail.com \\ Hulman Panjaitan \\ Department of Law, Faculty of Law, Universitas Kristen Indonesia \\ E-mail: panjaitanhulman90@gmail.com \\ L.Elly AM Pandiangan \\ Department of Law, Faculty of Law, Universitas Kristen Indonesia \\ E-mail: elly.pandiangan@uki.ac.id \\ I Dewi Ayu Widyani \\ Department of Law, Faculty of Law, Universitas Kristen Indonesia \\ E-mail: ayu.widyani@uki.ac.id
}

\begin{abstract}
Saniago Dakhi (Corresponding author)
English Education Department, Faculty of Teacher Training and Education, Universitas Kristen Indonesia Jalan Mayjen Sutoyo, Nomor 2

Jakarta 13630, Indonesia
\end{abstract}

Tel: 62-823-6767-5704; Fax: 62-21-809-2425

E-mail: saniagonias@gmail.com 
Received: September 18, 2018 Accepted: October 22, 2018 Published: November 12, 2018

doi:10.5296/jad.v4i2.13895 URL: https://doi.org/10.5296/jad.v4i2.13895

\begin{abstract}
A debatable consensus on and appropriate approaches to literature review function as the theoretical background of the paper. It redefines the literature review substance, synthesis, and procedure to literature matrix, and literature review assessment. In addition, some implications are to interpret the discussion. Finally, finding of the present study is applicable to any study fields at it generally provides matrix for which writing literature review can be easily conducted. Suggestions, identical to the potential of further studies and its application by on-going researcher and writer, are holistically provided.
\end{abstract}

Keywords: Synthesis matrix, literature, review, writing, assessment

\title{
1. Introduction
}

Intersegmental Committee of the Academic Senates (2002) stating true academic competence, more specifically scientific discourse, depending upon a set of perceptions and behaviors acquired while preparing for more advanced academic work, is definitely in a linear direction with Mah and Ifenthaler (2018) suggesting preparedness and realistic perceptions which are important factors for student retention. Writing a review, a productive written discourse competency and the most complex of the comprehension strategies (Deane et al., 2008), profoundly redefines its substantial purpose not a mere presentation of information and thought, but rather an actual communication (Gopen \& Swan, 1990) used to uncover what is already known in the body of knowledge prior to, and initiating any research studies (Järvinen, 2008). Additionally, it is obliged to be clearly organized, logically developed, and coherent (Intersegmental Committee of the Academic Senates, 2002). Fourteen review methodologies (Grant \& Bootht, 2009), such as critical review, literature review, mapping review/systematic map, meta-analysis, mixed studies/mixed methods review, overview, qualitative systematic review/qualitative evidence synthesis, rapid review, scoping review, state-of-the-art review, systematic review, systematic search and review, systematized review, and umbrella have to be taken into account by writers. Meta-narrative synthesis, critical interpretive synthesis, meta-study, meta-ethnography, grounded formal theory, thematic synthesis, textual narrative synthesis, framework synthesis and ecological triangulation (Barnett-Page, E. \& Thomas, n.d.), moreover, are approaches to qualitative synthesis.

It was argued one way that seems particularly helpful in organizing literature reviews, not a scholar's literature and synthesis evaluation (Foster, 2013), is the synthesis matrix, a chart allowing a researcher to sort and categorize the different arguments presented on an issue and an opposite procedure to analysis combining separated elements forming a coherent whole, Ritchey (1991). The literature review has been influencing the scholarly articles. Zhao and Hirvela (2015) reported the students' understanding of synthesis, and Haas and Flower (1988) studied the functions of sources which are playing a crucial role in learning to synthesize. 


\section{MInstitute ${ }^{\text {Mink }}$}

Knudson (1998) concluded that although synthesis instruction was less impressive, summarization was effective for improving both macro and micro skills in writing. More interestingly, both Puks (n.d.) who evaluated the software tools for supporting literature review and Mathews (2004) who developed a matrix approach to categorize the literature review of social and environmental accounting research have made the study on literature review broader. Finally, Klopper, Lubbe, and Rugbeer's review (2007) that the matrix analysis in Linguistics is to demonstrate phonemes, semantic features, and phonological changes drives the article to the perceived background redefining the literature review substance, procedure to literature review (Levy \& Ellis, 2006; Goldschmidt, 1986; Cronin, Ryan, \& Coughlan, 2007), synthesis matrix (Miles, Huberman, \& Saldaña, 2013; Onwuegbuzie \& Weinbaum, 2016; Klopper, Lubbe, \& Rugbeer, 2007; Burge, 2006; Khoo, $\mathrm{Na}, \&$ Jaidka, 2011) and literature review assessment (Boote \& Beile, 2005).

\section{Discussion}

\subsection{Redefining Information Synthesis}

The literature review, an indispensably complex task and a reading-writing task in research (Hu, 2010), is arguably the most challenging and daunting element in project reports for the novice writer (Sastry \& Mohammed, 2013; Dakhi, 2009). A debatable consensus of literature review notion, so-called information synthesis (Goldschmidt, 1986) and the vast dynamics of knowledge, including language (Dakhi, 2011), stimulate the scholar's effort to define and divide it. It is simply grouped into traditional (Booth, Sutton, \& Papaioannou, 2012) and systematic approach-based definitions (Cronin, Ryan, \& Coughlan, 2007). Criticism, summary, and inference are credited to the traditional process, an opposite to the systematic one as a selected relevant study procedurally applying identification, comprehension, application, analysis, and synthesis. More technically, a traditional definition or a non-systematic review, a basis of scholarly material, is poorly conducted and reported (Booth, Sutton, \& Papaioannou, 2012). Constructing the topic, the selection of methods, and demonstration that the research contributes something new (Webster \& Watson, 2002), not merely an elaborated bibliography of multiple research manuscripts, are what writer(s) do. In conjunction with Cronin, Ryan, and Coughlan's opinion (2007) it serves as the procedure of current up-to-date and existing literature on a topic as a justification for future research in the subject matter. An equally important support is Syun's, (2007) argument that the literature review is used as a medium and basis for testing hypothesis. Finally, a duplication avoidance, comparison and contrast, and conclusion drawing meet the conventional review objective, a firm foundation for advancing knowledge and facilitating theory development.

The systematic view, on the contrary, consists in Goldschmidt's definition as a meta-analysis, a statistical manipulation of findings from multiple research studies and an attempt to acquire an external research finding validity, identification, comprehension, application, analysis, and synthesis (Levy \& Ellis, 2006). This supports Samnani's et al. (2017) finding that it functions as a firm support of the subject-matter, analysis and synthesis, contributing to and creating potential further study and driving to a cyclically-document-centric process in scientific discourses including proposals, research papers, summary articles, books, policy and 
regulatory statements (Goldman \& Schmalz, 2004) made of.

Two distinctive styles of literature review, completing Azar and Hashim's classification (2014), i.e. art reviews, promotional reviews, and academic reviews, by which an inclusion and rejection of studies are descriptive and integrative literature review. The descriptive literature classifies the literature in a range of categories (Yang \& Tate, 2012) and summarizes individual work accommodating the research method appropriateness, research result discussion and interpretation. Secondly, integrative literature review provides critical summaries, generally, a reviewer's dominant voice appears, stimulating further research on the topic (Torraco, 2016), through which individual and collective complex work requiring collaboration and integration of knowledge from diverse subjects are identified (Soares et al., 2014). To coincide with their characteristics Jaidka, Khoo, and $\mathrm{Na}$ (2013) reported that the integrative literature reviews contain more research result information and critique, and the descriptive literature reviews contain more research method information.

\subsection{Procedure for Literature Review}

Although the urgency, approach, move, and procedure of literature reviews are debatable, some logically-extracted concepts reveal new insight. Khoo, Na, and Jaidka's (2011) functions of literature, namely source identification, comparing and contrasting previous research, identifying gaps in the literature, identifying issues, defining the proposed research contribution (Booth, Sutton, \& Papaioannou, 2012), building the foundation, situating and leading to new productive work (Boote \& Beile, 2005), and reinterpretation of results are executed into two varied approaches. They are a concept-centric approach, a method in which the concepts determine the review framework organization, and author-centric approach, an author-based review presenting a relevant article summary (Webster \& Watson, 2002).

Regardless of the difference, Levy and Ellis (2006) proposed three phases of literature review writing-input, process, and output. The input is an act of collecting theories and previous studies related (Reuber, 2010) signaling how well past research coverage was; while review process is a sequential step to collect, know, comprehend, apply, analyze, synthesize, and evaluate literature quality as a firm foundation to a topic and research method. Finally, the amount of fixed result of the review is called output.

On the contrary, Goldschmidt (1986) suggesting topic definition, i.e. to determine the relevant information, in addition to the other three steps, namely systematic information search-a process to find relevant information, validity assessment, namely to identify valid relevant information, and presentation of a relevant problem, valid information in a manner useful to the intended audience, precedes the input step by Levy and Ellis (2006). Furthermore, the Cronin, Ryan, and Coughlan's (2007) final step on processing, references generally restricted to those that have a direct bearing on the research being reported (Taylor, 2002) and public presentation (Randolph, 2009), have put the literature review practical steps into an acceptably applicable one. Similarly, Okoli and Schabram's systematic guide to literature review development (2010) consists of a planning-purpose of the literature review, and protocol and training, selection, i.e. searching the literature and practical screen, extraction allowing quality appraisal and data extraction, and execution-analysis of findings 
and writing the review.

A modified literature review move, e.g. Move 1, i.e. establishing one part of the territory of one's own research, and Move 2 -- creating a research niche -- are usually recursively applied. Unlikely Move 3, occupying the research niche, is credited to Kwan's (2006) literature review genre. Surveying the non-research-related phenomena or knowledge claims, claiming centrality, and surveying the non-research-related phenomena are strategies to achieve Move 1. Creating a research niche is met by counter-claiming, gap-indicating, usually deepening the understanding of how research gaps may be constituted and may thus help to identify research gaps in literature reviews (Müller-Bloch \& Kranz, 2015), asserting the relevancy of the surveyed claims to one's own research, and abstracting or synthesizing knowledge claims to establish a theoretical position or a theoretical framework. Finally, the steps occupying the research niche are research aims, focus, research questions or hypotheses, theoretical positions, research design, and interpretations of terminology used in the thesis.

\subsection{Synthesis Matrix as an Alternative to Literature Review}

A wide range of scholarly matrix definitions totally influences various notions of matrix, more specifically synthesis matrix. A matrix, an end goal to provide a visual representation of the analysis and synthesis of the information extracted from the literature review, is essentially the intersection of two lists, set up as rows and columns (Miles, Huberman, \& Saldaña, 2013, p. 109; Onwuegbuzie \& Weinbaum, 2016). Additionally, Klopper, Lubbe, and Rugbeer (2007) define matrix as a conceptual framework, a network, or "a plane" of interlinked concepts, that together provides a comprehensive understanding of a phenomenon or phenomena (Jabareen, 2009). They divide matrix into time-ordered matrix (publication date, demonstrating longitudinal aspects of the topic), role-ordered matrix containing verbal information about the view of role occupants on a specific issue of the project, checklist matrix (integrated data on a summative index or scale, thus organising several components of a single, coherent variable), conceptually-clustered matrix (a central theme, effects matrix, i.e. outcomes and dependent variables), site dynamics matrix (present forces that are at work in particular contexts showing processes and outcomes), event listing matrix, a series of events displayed in any possible order, and causal network matrix, a field of interrelationships between dependent and independent variables, describing causal connections between them.

Literature review, alternatively termed as a multi-criteria approach to review as it is worthy of validity and aids researchers and decision makers effectively applying the approaches (Ho, $\mathrm{Xu}$, \& Dey, 2010), is obliged to be functional. Miles and Huberman (1994, p. 240-241) as supported by Klopper, Lubbe, and Rugbeer (2007) stating that no correct matrices, only functional matrices is convincing. Hence, it allows identifying the presence and strengths of relationships between two or more lists of items (Burge, 2006) and requires the writer's creativity, proficiency, and originality of the matrix design. Additionally, the concept-centric matrix of literature review (Khoo, Na, \& Jaidka, 2011), matrix design entirely governed by the concepts, is congruent with the finest appropriate approach to review as it is oriented more on the optimization of the structure of energetic systems during the process of analyzing the intercorrelation and dependencies inside the chain and among its elements (Tkacz, 2010). 
Burge's matrix diagram purpose (2006), identifying the matrix lists, assembling the team that can inter-relate the lists, selecting the matrix type, choosing and defining the relationship symbols, identifying, discussing and capturing the matrix relationship and drawing conclusions are respectively realized in step 1, step 2, step 3, step 4, step 5, step 6, and step 7 . A good matrix is obliged to be systematic, i.e. explicit, transparent, methodologically objective, standardized, structured, and reproducible (Fink, 2005; Okoli \& Schabram, 2010; Booth, Sutton, \& Papaioannou, 2012). Treated as a philosophical background, matrices are not always two-dimensional arrays (Paseau, 2017). The L-type matrix allowing the relationships between two lists, T-type matrix, i.e. an effectively-joined and related two L-types, Y-type matrix (a combination of three L-types), X-type matrix (a combination of four L-types), C-type matrix (a cube representing three lists), and Quality Function Deployment (QFD) Type matrix (a simply L-type matrix with an ancillary list containing a many-to-one relationship investigating the relationship between sets of requirements are credited to Burge's matrix classification (2006).

Concerning the literature review concept-centric approach (Webster \& Watson, 2002; Khoo, $\mathrm{Na}$, \& Jaidka, 2011; Klopper \& Lubbe, 2012) and combining it with the L-type matrix, by Burge, are advisedly recommended as a method achieving the well-prepared pre-literature writing. It is an effective and practical procedure, as shown by Zaid (2011) that students wrote longer and richer drafts in the conditions of online concept-mapping and online reading before writing as it lowered the student-writing anxiety (Schweiker-Marr \& Marra, 2010). Literature matrix as the pre-writing strategy-phases of document development (Kellogg, 1990) may include L-type matrix model's simplicity, and concept-centric approach driving the key concepts embedded in the headings (Klopper \& Lubbe, 2012), identifying items below them (Publication Manual of the American Psychological Association, 2010, p. 133) and determining the structure and complexity of the tables (Fang et al., 2012).

\subsection{Literature Review Assessment}

Assessing literature review, requiring a scoring rubric that can provide a reliable and objective method for analysis and comparison (Knight, 2006) of an intended student's work, is integral to its completion as it is diagnostic and predicting. Lee et al. (2015) highlighting that a mathematics diagnostic test is not only useful for gaining information on a student's prior knowledge but is also one of the best predictors of future performance portraying the substantial significance of mathematics test. Subsequently, it addresses the literature review assessment. Similarly, Reddy and Andrade (2009) reported that studies of rubrics in higher education have been undertaken in a wide range of disciplines and for multiple purposes, including increasing student achievement, improving instruction and evaluating programmes. Furthermore, Johnsson and Svingby (2007) concluded that the reliable scoring of performance assessments can be enhanced by the use of rubrics, especially if they are analytic, topic-specific, and complemented with exemplars and or rater training; rubrics do not facilitate valid judgment of performance assessments per se; and rubrics seem to have the potential of promoting learning and or improve instruction. Finally, Andrade and Du (2005) reported that rubrics helped the students focus their efforts, produce work of higher quality, earn a better grade, and feel less anxious about an assignment. 
Distinctive rubrics of literature review have attracted a number of scholars' attention. Regardless of an institutionally-made rubric, Lovitts (2005) defined a literature review quality of dissertation into acceptable and unacceptable. More importantly, her literature review indicators-comprehensive and up-to-date, showing a command of literature, contextualizing the problem, and including a selective, synthetic, analytical, and thematic discussion-have not holistically produced an empirically-valid and reliable instrument. Finally, Boote and Beile (2005) as adopted by Randolph (2009) have well-defined a five-category rubric of literature review assessment-coverage, synthesis, methodology, significance, and rhetoric (a complete literature review rubric evaluation is appended to the article). Later in 2008, Green and Bowser (2006) developed, focusing on the process of adapting and testing it as an instructional and assessment instrument, Boote and Beile's model with an analytic rubric used with graduate literature reviews.

\section{Conclusion, Implication, and Suggestion}

\subsection{Conclusion}

Concerning the previous discussion, four well-defined concepts are drawn. Firstly, despite a debatable consensus of literature review account, one of the fourteen reviewing methodologies still exists, systematic view and integrative literature review, so-called information synthesis, formulate a frame-of-reference that literature review is a meta-analysis, the statistical manipulation of findings from multiple research studies. It is an attempt to acquire an external research finding validity, identification, comprehension, application, analysis, and synthesis stimulating further research on the topic. Secondly, concept-centric approach to the literature review, a method in which the concepts determine the review framework organization, building an input-process-output review, positively responds to the systematic procedure for a three-interrelated-move of literature review. Furthermore, a matrix allows the presence and strengths of relationships between two or more lists of items. A literature matrix is defined as the pre-writing strategy-phase of document development, and L-type matrix model's simplicity and concept-centric approach driving the key concepts embedded in the headings are considered worthy functional. Finally, an assessment is integral to the well-planned objective accomplishment of literature review as it is diagnostic and predicting. The only defined five-category rubric of literature review-coverage, synthesis, methodology, significance, and rhetoric has made an instrument accessing the literature review acceptance.

\subsection{Implication}

The following implications are derived from the discussion and conclusion. Firstly, even though the literature review procedure account has to be functionally applied, the literature matrix is still defined as the pre-writing strategy-phase of document development redefining it as a long-process academic product. Secondly, fourteen reviewing methodologies imply the complexity of review as it requires integrated skills, such as reading, analysis, synthesis, evaluation, and writing. Thirdly, the Klopper, Lubbe, and Rugbeer's matrix template absence (2007) results in, I term, a modified concept-centric model of L-type synthesis matrix as a manual and model for an on-going researcher. Fourthly, viewing academic discourse as a 
discourse science (Halliday \& Martin, 1993) and referring literature review rubric assessment, literature review has to be mathematically observed for its acceptance degree. Additionally, a foreign language learning style studied by Male (2017) acts as an additional account for reconsidering the Booth, Sutton, and Papaioannou's (2012) systematic literature review procedure as it revealed that any student has a diverse language learning style implying that the procedure is obliged to be associated with the learner's personality. Finally, concept-centric approach to and integrative-model of literature review denote a product-based writing approach.

\subsection{Suggestion}

A number of suggestions to respond to the conclusion are as follows.

1) Interesting-longitudinal studies on the modified concept-centric model of L-type synthesis matrix and the literature review assessment employing Boote and Beile's model (2005) are broadly accessible for empirically testing its effective acceptance and reliability.

2) Viewing matrix as an artificially-designed computer simulation of the entire physics of a world (Chalmers, 2005) suggests the matrix as metaphysics. Furthermore, L-type literature matrix model's simplicity viewed as a pre-writing process suggests its application to the scholarly work in any writing tasks and indicates its questionable conduct to the literary project.

3) As people have different language learning styles, researches on literature model matrix based on personalities will be interesting.

4) Since the present study is a theoretical review, the experimental study on effectiveness of the input-process-output model (Levy \& Ellis, 2006) and systematic guide to literature review development (Okoli \& Schabram, 2010) is challenging for further research.

\section{References}

Andrade, H. L., \& Du, Y. (2005). Student Perspectives on Rubric-Referenced Assessment. Educational \& Counseling Psychology Faculty Scholarship, 10(3). Retrieved from https://scholarsarchive.library.albany.edu/edpsych_fac_scholar/2

Azar, A. S., \& Hashim, A. (2014). Towards an analysis of review article in Applied Linguistics: Its classes, purposes and characteristics English Language Teaching, 7(10). https://doi.org/10.5539/elt.v7n10p76

Barnett-Page, E., \& Thomas, J. (2009). Methods for the synthesis of qualitative research: a critical review. BMC medical research methodology, 9(1), 59. Retrieved from http://eprints.ncrm.ac.uk/690/1/0109\%2520Qualitative\%2520synthesis\%2520methods\%250p aper\%2520NCRM.pdf

Boote, D. N., \& Beile, P. (2005). Scholars before researchers: On the centrality of the dissertation literature review in research preparation Educational Researcher, 34(6), 3-15.

Booth, A., Sutton, A., \& Papaioannou, D. (2012). A systematic approaches to a successful 
literature review. California: Sage Publication Inc.

Burge, S. (2006). The systems thinking toolbox. Retrieved from https://www.burgehugheswalsh.co.uk/uploaded/1/documents/md-tool-box-v1.0.pdf

Chalmers, D. J. (2005). The matrix as metaphysics. Retrieved from http://consc.net/papers/matrix.pdf

Cronin, P., Ryan, F., \& Coughlan, M. (2007). Undertaking a literature: A step-by-step-approach. British Journal of Nursing, 17(1), 38-43. https://doi.org/10.12968/bjon.2008.17.1.28059

Dakhi, S. (2011).Lexical changes of southern dialect of Li Niha. Jurnal Linguistik Terapan, $8(2), 85-106$. Retrieved from http://digilib.unimed.ac.id/3219/

Dakhi, S. (2009). Students'difficulties in reading English newspaper. Jurnal Littera, 2(1), 19-27. Retrieved from http://repository.uki.ac.id/267/

Deane, P., Odendahl, N., Quinlan, T., Fowles, M., Welsh, C., \& Bivens - Tatum, J. (2008). Cognitive models of writing: Writing proficiency as a complex integrated skill. ETS Research Report Series, 2008(2), i-36.

Fang, J., Mitra, P., Tang, Z., \& Giles, C. L. (2012, July). Table Header Detection and Classification. In AAAI (pp. 599-605). Retrieved from https://pdfs.semanticscholar.org/2e4c/cf5445490a176dabdf77a5e39cb11f88970c.pdf

Fink, A. (2005). Conducting Research Literature Reviews: From the Internet to Paper. Thousand Oaks California: Sage Publications.

Foster, R. (2013). Literature search and data synthesis methods for estimating inputs for health, economic modeling (Technical Report). Retrieved from https://www.otago.ac.nz/wellington/otago042138.pdf

Goldman, K. D., \& Schmalz, K. J. (2004). The matrix method of literature review HealthPromotion Practice, 5(1). https://doi.org/10.1177/1524839903258885

Goldschmidt, P. G. (1986). Information Synthesis Health service. Research Retrieved from http://jameslindlibrary.org/wp-data/uploads/2014/06/Goldschmidt_1986_whole_article.pdf

Gopen, G. D., \& Swan, J. A. (1990). The science of scientific writing. Retrieved from http://www.sdc.uwo.ca/writing/img/pdfs/The-Science-of-Scientific-Writing.pdf

Grant, M. J., \& Bootht, A. (2009). A typology of reviews: An analysis of 14 review types and associated methodologies. Health Information and Libraries Journal, 26, 91-108. https://doi.org/10.1111/j.1471-1842.2009.00848.x

Green, R., \& Bowser, M. (2006). Observations from the field. Journal of Library Administration, 45(1-2). 185-202. https://doi.org/10.1300/J111v45n01_10

Haas, C., \& Flower, L. (1988). Rhetorical reading strategies and the construction of meaning. College Composition and Communication, 39(2), 167-183. https://doi.org/10.2307/358026 


\section{Macrothink}

Halliday, M. A. K., \& Martin, J. R. (1993). Writing science: Literacy and discursive power. London: Falmer Press.

Ho, W., Xu, X., \& Dey, P. K. (2010). Multi-criteria decision approaches for supplier evaluation and selection: A literature review. European Journal of Operational Research, 202(1). https://doi.org/10.1016/j.ejor.2009.05.009

$\mathrm{Hu}$, J. (2010). The schematic structure of literature review in research articles of Applied Linguistics. Chinese Journal of Applied Linguistics, 33(5), 15-37.

Intersegmental Committee of the Academic Senates. (2002). Academic Literacy: A Statement of Competencies Expected of Students Entering California's Public Colleges and Universities Retrieved from https://senate.universityofcalifornia.edu/_files/reports/acadlit.pdf

Jaidka, K., Khoo, C. S. G., \& Na, J. C. (2013). Literature review writing: How information is selected and transformed. Aslib Proceedings, 65(3), 303-325. https://doi.org/10.1108/00012531311330665

Jabareen, Y. (2009). Building a conceptual framework: Philosophy definition and procedure. International Journal of Qualitative Methods, 8(4), 49-62.

Järvinen, P. (2008). On developing and evaluating of the literature review. Retrieved from http://www.sis.uta.fi/cs/reports/dsarja/D-2008-10.pdf

Johnsson, A., \& Svingby, G. (2007). The use of scoring rubrics: Reliability validity and educational consequences. Educational Research Review, 2(2), 130-144. https://doi.org/10.1016/j.edurev.2007.05.002

Kellogg, R. T. (1990). Effectiveness of prewriting strategies as a function of task demands. The American Journal of Psychology, 103(3), 327-342. https://doi.org/10.2307/1423213

Khoo, C. S. G., Na, J - C., \& Jaidka, K. (2011). Analysis of the macro - level discourse structure of literature reviews. Online Information Review, 35(2), 255 - 271.

Klopper, R., \& Lubbe, S. (2012). Using matrix to achieve traction coherence progression and closure in problem-solution oriented research. Retrieved from http://aisel.aisnet.org/cgi/viewcontent.cgi?article=1018\&context=confirm 2012

Klopper, R., Lubbe, S., \& Rugbeer, H. (2007). The matrix method of literature review. Alternation, 14(1), 1-17.

Knight, L. A. (2006). Using rubrics to assess information literacy. Reference Services Review, 34(1), 43-55. https://doi.org/10.1108/00907320610640752

Knudson, R. E. (1998). College students' writing: An assessment of competence. The Journal of Educational Research, 92(1), 13-19. https://doi.org/10.1080/00220679809597571

Kwan, B. S. C. (2006). The schematic structure of literature reviews in doctoral theses of applied linguistics. English for Specific Purposes, 25(1). $30 \quad-55$. https://doi.org/10.1016/j.esp.2005.06.001 


\section{Macrothink}

Journal of Asian Development

ISSN 2377-9594

2018, Vol. 4, No. 2

Levy, Y., \& Ellis, T. J. (2006). A system approach to conduct an effective literature review in support of information system research (E Cohen Ed). Informing Science Journal, 9(37).

Lovitts, B. E. (2005). How to grade a dissertation. Academe November/December 2005 Issue. Retrieved from https://www.ittc.ku.edu/ frost/How_to_grade_disseration_Academe_Article.pdf

Male, H. (2017). EFL undergraduate students' learning style preferences. The 3rd International Indonesian Forum for Asian studies.

Mah, D. K. \& Ifenthaler. (2018). Students' perception toward academic competencies: The case of German first-year students. Issues in Education Research, 28(1). Retrieved from http://www.iier.org.au/iier28/mah.pdf

Mathew, s R. (2004). Developing a matrix approach to categorise the social and environmental accounting research literature. Qualitative Research in Accounting \& Management, 1(1), 30-45. https://doi.org/10.1108/11766090410816280

Miles, M. B., Huberman, A. M., \& Saldaña, J. (2013). Qualitative data analysis: A methods Sourcebook. London: Sage Publication.

Müller-Bloch, C., \& Kranz, J. (2015). A framework for rigorously identifying research gaps in qualitative literature reviews. Retrieved from https://pdfs.semanticscholar.org/89e6/a54cbe7240488d88ce49b51fc83c7186d564.pdf

Okoli, C., \& Schabram, K. (2010). A guide to conducting a systematic literature review of information systems research. Sprouts: Working Papers on Information Systems, 10(26), 1-50. Retrieved from http://sprouts.aisnet.org/10-26

Onwuegbuzie, A. J., \& Weinbaum, R. K. (2016). Mapping Miles and Huberman's within-case and cross-case analysis methods onto the literature review process. Journal of Educational Issues, 2(1), 265-288.

Paseau, A. C. (2017). Philosophy of the matrix. Philosophia Mathematica, 25(2), 246-267.

Puks R (nd). Software tools for supporting literature review: An overview and a case, (Master Thesis. $\quad$ Retrieved from https://www.google.com/url?sa=t\&rct=j\&q=\&esrc=s\&source=web\&cd=1\&ved=0ahUKEwj GjMfdlM_aAhXMQo8KHfEgCyYQFghIMAA\&url=http\%3A\%2F\%2Fwww.cs.tlu.ee\%2Ft eemad\%2Fget_file.php\%3Fid\%3D449\&usg=AOvVaw3Ug5KjpSv6ZiyJEke_BXE5

Randolph, J. J. (2009). A guide to writing the dissertation literature review Practical Assessment, Research \& Evaluation, 4(13), 1-13. https://doi.org/10.1080/02602930902862859

Reuber, A. R. (2010). Strengthening your literature review. Family Business Review, 23(2),105-108.

Reddy, Y. M., \& Andrade, H. (2010). A review of rubric use in higher education. ssessment \& evaluation in higher education, 5(4), 435-448. 
Ritchey, T. (1991). Analysis and synthesis: on scientific method-based on a study by Bernhard Riemann. ystems research, (4), 21-41. Retrieved from http://www.swemorph.com/pdf/anaeng-r.pdf

Samnani, S. S., Vaska, M., Ahmed, S., \& Turin, T. C. (2017). Review Typology: The Basic Types of Reviews for Synthesizing Evidence for the Purpose of Knowledge Translation. Journal of the College of Physicians and Surgeons--Pakistan: JCPSP, 27(10), 635-641.

Sastry, M. K., \& Mohammed, C. (2013, July). The summary-comparison matrix: A tool for writing the literature review. In Professional Communication Conference (IPCC), 2013 IEEE International pp. (1-5). IEEE from https://ieeexplore.ieee.org/abstract/document/6623891/

Soares, C. B., Hoga, L. A. K., Peduzzi, M., Sangaleti, C., Yonekura, T., \& Silva, D. R. A. D. (2014). Integrative review: concepts and methods used in nursing. Revista da Escola de Enfermagem da USP, 48(2), 335-345. Retrieved from http://www.scielo.br/pdf/reeusp/v48n2/0080-6234-reeusp-48-02-335.pdf

Schweiker-Marra, K. E., \& Marra, W. T. (2000). Investigating the effects of prewriting activities on writing performance and anxiety of at-risk students. Reading Psychology, 21(2), 99-114. Retrieved from https://doi.org/10.1080/02702710050084437

Akasofu, S. I. (2007). The importance of synthesis: A suggestion for international research efforts. Eos, Transactions American Geophysical Union, 88(25), 264-264. https://doi.org/10.1029/2007EO250007

Taylor, D. M. (2002). The appropriate use of references in a scientific research paper. Emergency Medicine, 14(2), 166-170. Retrieved from https://pdfs.semanticscholar.org/9db3/8b5f3cd180797529fb9e6da329f904d6faa3.pdfhttps://d oi.org/10.1046/j.1442-2026.2002.00312.x

Torraco, R. J. (2016). Writing integrative literature reviews: Using the past and present to explore the future. Human Resource Development Review, 15(4), 404-428. https://doi.org/10.1177/1534484316671606

Tkacz, W. W. (2010). The use of the matrix diagram as a tool for the analysis of effectiveness of supply chain. In $\log$ Forum (Vol. 6, No. 2, p. 4). Retrieved from http://www.logforum.net/vol6/issue2/no4

Webster, J., \& Watson, R. T. (2002). Analyzing the past to prepare for the future: Writing a literature review. MIS quarterly, xiii-xxiii. Retrieved from https://web.njit.edu/ egan/Writing_A_Literature_Review.pdf

Yang, H., \& Tate, M. (2012). A descriptive literature review and classification of cloud computing research. CAIS, 31, 2 Retrieved from http://aisel.aisnet.org/cais/vol31/iss1/2

Zhao, R., \& Hirvela, A. (2015). Undergraduate ESL Students' Engagement in Academic Reading and Writing in Learning to Write a Synthesis Paper. Reading in a Foreign Language, 27(2), 219-241 
Zaid, M. A. (2011). Effects of web-based pre-writing activities on college EFL students' writing performance and their writing apprehension. Journal of King Saud University-Languages and Translation, 23(2), 77-85.

Appendix A

\begin{tabular}{|c|c|c|c|c|}
\hline Category & Criterion & 1 & 2 & 3 \\
\hline 1. Coverage & $\begin{array}{l}\text { A. Justified criteria for } \\
\text { inclusion and exclusion } \\
\text { from review }\end{array}$ & $\begin{array}{l}\text { Did not discuss } \\
\text { the criteria for } \\
\text { inclusion } \\
\text { exclusion }\end{array}$ & $\begin{array}{l}\text { Discussed the } \\
\text { literature included } \\
\text { and excluded }\end{array}$ & $\begin{array}{l}\text { Justified inclusion } \\
\text { and exclusion of } \\
\text { literature }\end{array}$ \\
\hline \multirow{6}{*}{ 2. Synthesis } & $\begin{array}{l}\text { B. Distinguished } \\
\text { between what has been } \\
\text { done in the field and what } \\
\text { needs to be done }\end{array}$ & $\begin{array}{l}\text { Did not } \\
\text { distinguish what } \\
\text { has and has not } \\
\text { been done before }\end{array}$ & $\begin{array}{l}\text { Discussed what } \\
\text { has and has not } \\
\text { been done }\end{array}$ & $\begin{array}{l}\text { Critically } \\
\text { examined the state } \\
\text { of the field }\end{array}$ \\
\hline & $\begin{array}{l}\text { C. Placed the topic or } \\
\text { problem in the broader } \\
\text { scholarly literature }\end{array}$ & $\begin{array}{l}\text { Topic not placed } \\
\text { in } \quad \text { broader } \\
\text { scholarly } \\
\text { literature }\end{array}$ & $\begin{array}{l}\text { Some discussion of } \\
\text { broader scholarly } \\
\text { literature }\end{array}$ & $\begin{array}{l}\text { Topic clearly } \\
\text { situated in broader } \\
\text { scholarly } \\
\text { literature }\end{array}$ \\
\hline & $\begin{array}{l}\text { D. Placed the research } \\
\text { in the historical context of } \\
\text { the field }\end{array}$ & $\begin{array}{l}\text { History of topic } \\
\text { not discussed }\end{array}$ & $\begin{array}{l}\text { Some mention of } \\
\text { the history of topic }\end{array}$ & $\begin{array}{l}\text { Critically } \\
\text { examined history } \\
\text { of topic }\end{array}$ \\
\hline & 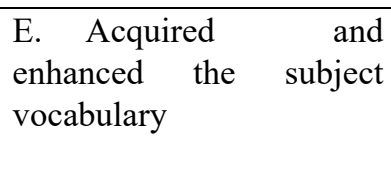 & $\begin{array}{l}\text { Key vocabulary } \\
\text { not discussed }\end{array}$ & $\begin{array}{l}\text { Key vocabulary } \\
\text { defined }\end{array}$ & $\begin{array}{ll}\text { Discussed } & \text { and } \\
\text { resolved } & \\
\text { ambiguities } & \text { in } \\
\text { definitions } & \end{array}$ \\
\hline & $\begin{array}{l}\text { F. Articulated } \\
\text { important variables and } \\
\text { phenomena relevant to the } \\
\text { topic }\end{array}$ & $\begin{array}{l}\text { Key variables and } \\
\text { phenomena not } \\
\text { discussed }\end{array}$ & $\begin{array}{l}\text { Reviewed } \\
\text { relationships } \\
\text { among } \\
\text { variables } \\
\text { phenomena }\end{array}$ & $\begin{array}{l}\text { Noted ambiguities } \\
\text { in literature and } \\
\text { proposed new } \\
\text { relationships }\end{array}$ \\
\hline & $\begin{array}{l}\text { G. Synthesized and } \\
\text { gained a new perspective } \\
\text { on the literature }\end{array}$ & $\begin{array}{l}\text { Accepted } \\
\text { literature at face } \\
\text { value }\end{array}$ & $\begin{array}{l}\text { Some critique of } \\
\text { literature }\end{array}$ & $\begin{array}{ll}\text { Offered } & \text { new } \\
\text { perspective } & \end{array}$ \\
\hline 3. Methodology & $\begin{array}{l}\text { H. Identified the main } \\
\text { methodologies and } \\
\text { research techniques that } \\
\text { have been used in the } \\
\text { field, and their advantages } \\
\text { and disadvantages }\end{array}$ & $\begin{array}{l}\text { Research methods } \\
\text { not discussed }\end{array}$ & $\begin{array}{l}\text { Some discussion of } \\
\text { research methods } \\
\text { used to produce } \\
\text { claims }\end{array}$ & $\begin{array}{l}\text { Critiqued research } \\
\text { methods }\end{array}$ \\
\hline
\end{tabular}

I. Related ideas and Research methods Some discussion of Critiqued theories in the field to not discussed appropriateness of research methodologies. research methods to warrant claims

appropriateness of research methods to warrant claims

J. Rationalized the Practical Practical practical significance of significance of significance
Critiqued appropriateness of 


\begin{tabular}{|c|c|c|c|c|}
\hline & the research problem & $\begin{array}{l}\text { research } \\
\text { discussed }\end{array}$ & discussed & $\begin{array}{l}\text { research methods } \\
\text { to warrant claims }\end{array}$ \\
\hline & $\begin{array}{l}\text { K. Rationalized the } \\
\text { scholarly significance of } \\
\text { the problem }\end{array}$ & $\begin{array}{l}\text { Scholarly } \\
\text { significance } \\
\text { research } \\
\text { discussed }\end{array}$ & $\begin{array}{l}\text { Scholarly } \\
\text { significance } \\
\text { discussed }\end{array}$ & $\begin{array}{l}\text { Critiqued } \\
\text { scholarly } \\
\text { significance } \\
\text { research }\end{array}$ \\
\hline 5. Rhetoric & $\begin{array}{l}\text { L. Was written with a } \\
\text { coherent, clear structure } \\
\text { that supported the review }\end{array}$ & $\begin{array}{l}\text { Poorly } \\
\text { conceptualized, } \\
\text { haphazard }\end{array}$ & $\begin{array}{ll}\begin{array}{l}\text { Some } \\
\text { structure }\end{array} & \text { coherent }\end{array}$ & $\begin{array}{l}\text { Well developed, } \\
\text { coherent }\end{array}$ \\
\hline
\end{tabular}

The Rubric of Literature Review Adopted by Boote and Beile (2005)

\section{Copyright Disclaimer}

Copyright for this article is retained by the author(s), with first publication rights granted to the journal.

This is an open-access article distributed under the terms and conditions of the Creative Commons Attribution license (http://creativecommons.org/licenses/by/4.0/). 